\title{
Vitamin D Status in Prediabetes and its Different Categories
}

Md. Shahed Morshed ${ }^{* 1}$; Md. Fariduddin²; Tahniyah Haq ${ }^{2}$; Shahjada Selim ${ }^{3}$; Murshed Ahamed Khan ${ }^{4}$; MA Hasanat ; Marufa Mustari ${ }^{6}$; Mostafa Hasan Rajib ${ }^{6}$; Anil Yadav ${ }^{7}$; Ibrahim Faisal ${ }^{8}$; Habibul Ghani ${ }^{9}$; Anil Kumar Shah ${ }^{10}$

\section{Abstract}

Objectives: Data regarding vitamin D level and status among categories of prediabetes are scarce in the literature. This study is aimed to determine the level and status of vitamin D among adults with prediabetes and its different categories. Materials and methods: This crosssectional study was carried out in 111 newly detected adults with prediabetes according to American Diabetes Association 2018 criteria and 74 matched healthy control (normal glucose tolerance). People with prediabetes were categorized into impaired glucose tolerance, impaired fasting glucose and their combination group. Participants were recruited consecutively from the Department of Endocrinology, BSMMU to measure serum 25 hydroxyvitamin D by high performance liquid chromatography and serum intact parathormone, calcium, albumin and phosphate by chemiluminescent enzyme-labeled immunometric assay. Results: Vitamin D level and status were not significantly different between people with prediabetes \& control and also in different categories of prediabetes. Severe vitamin D deficiency was significantly higher in people with prediabetes $(27.5 \%$ vs $10 \%, \mathrm{p}=0.05)$. There were no associations between different blood glucose levels with vitamin D among adults with prediabetes. Conclusions:Vitamin D was not associated with prediabetes or its categories.

Keywords: categories of prediabetes; impaired fasting glucose; impaired glucose tolerance; vitamin D

\section{Introduction}

Diabetes mellitus (DM) is one of the rapidly growing health care challenges due to its burden in the form of morbidity, mortality and health care cost. Prevention of diabetes is now an urgent requirement to reduce these troubles ${ }^{1}$. Prediabetes is the early stage of diabetes and major modifiable risk factors to prevent the progression of prediabetes to $\mathrm{DM}^{2}$. Several factors in the pathogenesis of DM are coming forward. A new theory of dirty dozen has been described that includes vitamin $\mathrm{D}$ due to its probable role in several pathways in the pathogenesis of $\mathrm{DM}^{3}$.

1. Md. Shahed Morshed, Kurmitola general hospital, Cantonment, Dhaka-1206, Bangladesh

2. Md. Fariduddin

3. Tahniyah Haq

4. Shahjada Selim

5. Murshed Ahamed Khan

6. MA Hasanat

7. Marufa Mustari

8. Mostafa Hasan Rajib Department of Endocrinology, Bangabandhu Sheikh Mujib Medical University, Shahbag, Dhaka-1000, Bangladesh

9. Anil Yadav, Department of internal medicine (Endocrinology division), Biratnagar medical college teaching hospital, Biratnagar, Nepal.

10. Ibrahim Faisal, Indira Gandhi memorial hospital, Male', Republic of Maldives.

11. Habibul Ghani, Jinjira 20 beded hospital, Keranigonj, Dhaka.

12. Anil Kumar Shah, Department of Medicine (Endocrinology unit), Chitwan medical college, Chitwan, Nepal.

Correspondence: Md. Shahed Morshed, Emergency medical officer, Kurmitola general hospital, Cantonment, Dhaka. e-mail: shahedk62@gmail.com. ORCID iD: https://orcid.org/0000-0001-6115-2655 
Hypovitaminosis D increases insulin resistance by secondary hyperparathyroidism and by reducing the expression of insulin receptors and peroxisome proliferator activated receptors. Low vitamin D is also associated with meta-inflammation, activation of renin-angiotensin system, reduced expression of insulin gene \& calbindin and direct $\beta$-cell dysfunction. All are responsible for diminished insulin production ${ }^{4}$. Recent studies suggest that vitamin $\mathrm{D}$ deficiency is a pandemic condition in healthy people even in areas of abundant sunshines. A recent study conducted in the city of Dhaka found a prevalence of $43.8 \%$ of vitamin D deficiency among unselected people ${ }^{6}$. Two studies published from Bangladesh also found around one third of patients with DM with vitamin D deficiency ${ }^{7,8}$. Another group of authors also found significantly lower level of vitamin D level in prediabetis with nonalcoholic fatty liver disease ${ }^{9}$.

But vitamin D level and status among Bangladeshi adults with only prediabetes were not published as per our best knowledge. Although many studies described the vitamin D level and status in adults with prediabetes, but their distribution according to different categories of prediabetes were rarely mentioned simultaneously in the literature.

Materials and methods

\section{Subjects}

This was a cross-sectional study. It was done in the department of Endocrinology of BSMMU among 111 newly detected adults with prediabetes and 74 age group and sex-matched control. Participants who were taking or had received vitamin D or calcium within last 120 days of sample collection; taking any medications that alter vitamin D level; having any disorders affecting vitamin $\mathrm{D}$ metabolism and pregnancy or lactation were excluded from the study. Participants were recruited consecutively by purposive sampling technique during the period of July 2018 to September 2019.

\section{Operational definitions}

Prediabetes was diagnosed by American Diabetes Association 2018 criteria \{impaired fasting glucose, IFG $(5.6-6.9 \mathrm{mmol} / \mathrm{L})$; impaired glucose tolerance, IGT $(7.8-11 \mathrm{mmol} / \mathrm{L})$ and HbA1c $39-47 \mathrm{mmol} /$ mol $(5.7-6.4 \%)\}^{2}$. Categories of prediabetes were described by oral glucose tolerance test (OGTT) as IGT, IFG and their combination group (IGT+IFG) and healthy control adults were considered as normal glucose tolerance (NGT) group. Vitamin D status was defined by Endocrine society's clinical practice guideline, 2011 into sufficiency $(\geq 30 \mathrm{ng} / \mathrm{ml})$, insufficiency $(20-29.99 \mathrm{ng} / \mathrm{ml})$ and deficiency $(<20$ $\mathrm{ng} / \mathrm{ml})^{10}$. Vitamin D deficiency status was further classified by Lips's criteria in to mild $(10-19.99 \mathrm{ng} /$ $\mathrm{ml})$, moderate $(5-9.99 \mathrm{ng} / \mathrm{ml})$ and severe $(<5 \mathrm{ng} / \mathrm{ml})$ vitamin D deficiency status ${ }^{11}$.

\section{Clinical data collection}

Data were collected in a semi-structured pretested questionnaire. Patients were asked regarding sociodemographic factors and factors affecting vitamin D level. Height, weight, waist circumference and blood pressure were measured as per standard methods.

\section{Biochemical analysis}

About $10 \mathrm{ml}$ of venous blood was taken from each participant in the fasting state. Serum was separated by centrifugation and stored in $-20^{\circ} \mathrm{C}$ until assay. Assay of the collected samples were done for 25 hydroxyvitamin $\mathrm{D}\{25(\mathrm{OH}) \mathrm{D}\}$ by high performance liquid chromatography method (HPLC) in SIL 20 series prominence HPLC analyzer with a coefficient of variability $2.6-4.9 \%$. Serum intact parathormone (iPTH), fasting serum calcium, albumin and phosphate were measured with chemiluminescent enzyme-labeled immunometric assay by Immulite 2000 systems Siemens, USA analyzer. Corrected calcium was calculated from fasting calcium and albumin by correction formula \{corrected calcium $(\mathrm{mg} / \mathrm{dl})=$ measured calcium $(\mathrm{mg} / \mathrm{dl})+0.8 \times(4-$ measured albumin in $\mathrm{gm} / \mathrm{dl})\}$.

\section{Data management}

Data were analyzed by computer based SPSS program (version 22.0). Data were expressed as frequencies or percentages for qualitative values and mean ( \pm standard deviation) for quantitative values. To compare the mean value (vitamin D, corrected calcium, serum inorganic phosphate and iPTH level) of subgroups, independent-samples $\mathrm{T}$ test or one way ANOVA was used as appropriate. To test the association between categories (sociodemographic variables and factors related to vitamin D level, vitamin D status) of the study population and prediabetes categories, Chi-square test or Fisher's exact test was done as applicable. Pearson's correlation test was used to correlate fasting, 2 hours OGTT glucose levels and $\mathrm{HbA1c} \%$ with vitamin D. Logistic regression analysis was done to see whether severe vitamin D deficiency could increase the risk 
of development of prediabetes or any prediabetes category. Statistically significant was set at $p$ value $<0.05$.

\section{Ethical considerations}

Informed consent was taken from each participant. The study protocol was approved by institutional review board of BSMMU (No. BSMMU/2018/4826).

Results

This study included 111 adults with prediabetes and 74 matched control population (NGT) to determine the vitamin $\mathrm{D}$ level and status in adults with prediabetes and its different categories. The prediabetes categories of IFG, IGT and IFG+IGT included 31 (27.93\%), 30 (27.03\%) and $50(45.05 \%)$ individuals respectively.
The mean age of the study population was not significantly different among different categories of glucose tolerance $(\mathrm{NGT}=37.34 \pm 10.82$ vs $\mathrm{IGT}=$ $34.10 \pm 9.52$ vs $\mathrm{IFG}=34.26 \pm 7.34$ vs $\mathrm{IGT}+\mathrm{IFG}=$ $39.68 \pm 11.15 ; p=0.07)$. The predominant categories of gender and area of residence in the study participants were female and urban respectively without any significant association among different study groups. There was a significant association between occupational classifications between prediabetes and control group due to higher percentages of manual unskilled class in the group with prediabetes than the control group. There was no significant association found between either educational status or socioeconomic status with different study groups (Table 1).

Table 1. Socio-demographic characteristics of the study population $(\mathbf{N}=185)$

\begin{tabular}{|c|c|c|c|c|c|c|c|c|}
\hline \multirow{3}{*}{ Variables } & \multirow{3}{*}{ Predominant category } & \multirow{2}{*}{$\begin{array}{c}\text { Prediabetes } \\
n=111\end{array}$} & \multirow{2}{*}{$\begin{array}{c}\text { Control } \\
\text { (NGT) } \\
n=74\end{array}$} & \multirow{3}{*}{$\mathrm{p}$} & \multicolumn{3}{|c|}{ Prediabetes categories } & \multirow{3}{*}{$\mathrm{p}$} \\
\hline & & & & & $\begin{array}{c}\text { IFG } \\
n=31\end{array}$ & $\begin{array}{c}\text { IGT } \\
\mathrm{n}=30\end{array}$ & $\begin{array}{r}\mathrm{IGT}+\mathrm{IFG} \\
\mathrm{n}=50\end{array}$ & \\
\hline & & \multicolumn{2}{|c|}{ frequency $(\%)$} & & \multicolumn{3}{|c|}{ frequency $(\%)$} & \\
\hline Gender & Female & $\begin{array}{c}88 \\
(79.3)\end{array}$ & $\begin{array}{c}59 \\
(79.7)\end{array}$ & 0.94 & $\begin{array}{c}26 \\
(83.9)\end{array}$ & $\begin{array}{c}22 \\
(73.3)\end{array}$ & $\begin{array}{c}40 \\
(80.0)\end{array}$ & 0.59 \\
\hline Area of residence $T$ & Urban & $\begin{array}{c}85 \\
(76.6)\end{array}$ & $\begin{array}{c}48 \\
(64.9)\end{array}$ & 0.08 & $\begin{array}{c}27 \\
(87.1)\end{array}$ & $\begin{array}{c}22 \\
(73.3)\end{array}$ & $\begin{array}{c}36 \\
(72.0)\end{array}$ & 0.26 \\
\hline $\begin{array}{l}\text { Occupational } \\
\text { classification } \neq\end{array}$ & Manual unskilled & $\begin{array}{c}72 \\
(64.9)\end{array}$ & $\begin{array}{c}30 \\
(40.5)\end{array}$ & $<0.001$ & $\begin{array}{c}18 \\
(58.1)\end{array}$ & $\begin{array}{c}21 \\
(70.0)\end{array}$ & $\begin{array}{c}33 \\
(66.0)\end{array}$ & 0.51 \\
\hline Educational status & $\begin{array}{l}\text { Completed higher } \\
\text { secondary }\end{array}$ & $\begin{array}{c}43 \\
(38.7)\end{array}$ & $\begin{array}{c}27 \\
(36.5)\end{array}$ & 0.60 & $\begin{array}{c}17 \\
(54.8)\end{array}$ & $\begin{array}{c}11 \\
(36.7)\end{array}$ & $\begin{array}{c}15 \\
(30.0)\end{array}$ & 0.41 \\
\hline $\begin{array}{l}\text { Socioeconomic } \\
\text { status } ¥\end{array}$ & Low & $\begin{array}{c}50 \\
(45.0)\end{array}$ & $\begin{array}{c}32 \\
(43.2)\end{array}$ & 0.95 & $\begin{array}{c}13 \\
(41.9)\end{array}$ & $\begin{array}{c}12 \\
(40.0)\end{array}$ & $\begin{array}{c}25 \\
(50.0)\end{array}$ & 0.82 \\
\hline
\end{tabular}

Within parenthesis are percentages over total column of respective variable

Chi-square test or Fisher's exact test was done as appropriate

T According to Bangladesh national conservation strategy ${ }^{11}$

$\neq$ According to registrar general occupational classification ${ }^{12}$

$¥$ According to monthly household income ${ }^{13}$

The participants with prediabetes were significantly more obese and centrally obese than the control population. There were no significant associations among other variables including sunlight exposure time with the different study groups (Table 2). 
Table 2. Variables related to vitamin $D$ level in the study population $(N=185)$

\begin{tabular}{|c|c|c|c|c|c|c|c|}
\hline \multirow{3}{*}{ Variables } & \multirow{2}{*}{$\begin{array}{c}\text { Prediabetes } \\
n=111\end{array}$} & \multirow{2}{*}{$\begin{array}{c}\text { Control (NGT) } \\
n=74\end{array}$} & \multirow{3}{*}{$\mathrm{p}$} & \multicolumn{3}{|c|}{ Prediabetes categories } & \multirow{3}{*}{$\mathrm{p}$} \\
\hline & & & & $\begin{array}{l}\text { IFG } \\
\mathrm{n}=31\end{array}$ & $\begin{array}{c}\text { IGT } \\
\mathrm{n}=30\end{array}$ & $\begin{array}{c}\mathrm{IFG}+\mathrm{IGT} \\
\mathrm{n}=50\end{array}$ & \\
\hline & \multicolumn{2}{|c|}{ frequency $(\%)$} & & \multicolumn{3}{|c|}{ frequency $(\%)$} & \\
\hline 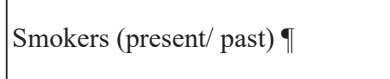 & $\begin{array}{c}19 \\
(17.1)\end{array}$ & $\begin{array}{c}11 \\
(14.9)\end{array}$ & 0.68 & $\begin{array}{c}6 \\
(19.4)\end{array}$ & $\begin{array}{c}8 \\
(26.7)\end{array}$ & $\begin{array}{c}5 \\
(10.0)\end{array}$ & 0.15 \\
\hline Physical activity level (Low) $¥$ & $\begin{array}{c}54 \\
(48.6)\end{array}$ & $\begin{array}{c}32 \\
(43.2)\end{array}$ & 0.34 & $\begin{array}{c}12 \\
(38.7)\end{array}$ & $\begin{array}{c}14 \\
(46.7)\end{array}$ & $\begin{array}{c}28 \\
(56.0)\end{array}$ & 0.35 \\
\hline $\begin{array}{l}\text { Adequate sunlight exposure } \\
\text { time } \dagger\end{array}$ & $\begin{array}{c}66 \\
(59.5)\end{array}$ & $\begin{array}{c}43 \\
(58.1)\end{array}$ & 0.86 & $21(67.7)$ & $\begin{array}{c}17 \\
(56.7)\end{array}$ & $\begin{array}{c}28 \\
(56.0)\end{array}$ & 0.08 \\
\hline $\begin{array}{l}\text { Sunlight exposure } \geq 20 \% \text { of body } \\
\text { surface area }\end{array}$ & $\begin{array}{c}23 \\
(20.7)\end{array}$ & $\begin{array}{c}14 \\
(18.9)\end{array}$ & 0.76 & $\begin{array}{c}5 \\
(16.1)\end{array}$ & $\begin{array}{c}6 \\
(20.0)\end{array}$ & $\begin{array}{c}12 \\
(24.0)\end{array}$ & 0.79 \\
\hline $\begin{array}{l}\text { Use of sunscreen (sun protecting } \\
\text { factor }>8 \text { ) }\end{array}$ & $\begin{array}{c}5 \\
(4.5)\end{array}$ & $\begin{array}{c}2 \\
(2.7)\end{array}$ & 0.70 & $\begin{array}{c}2 \\
(6.5)\end{array}$ & $\begin{array}{c}1 \\
(3.3)\end{array}$ & $\begin{array}{c}2 \\
(4.0)\end{array}$ & 0.86 \\
\hline Obesity $\Phi$ & $\begin{array}{c}88 \\
(79.3)\end{array}$ & $\begin{array}{c}39 \\
(52.7)\end{array}$ & 0.001 & $23(74.2)$ & $\begin{array}{c}23 \\
(76.7)\end{array}$ & $\begin{array}{c}42 \\
(84.0)\end{array}$ & 0.60 \\
\hline Central obesity $\Phi$ & $\begin{array}{l}101 \\
(91)\end{array}$ & $\begin{array}{c}54 \\
(73.0)\end{array}$ & 0.001 & $28(90.3)$ & $\begin{array}{c}27 \\
(90.0)\end{array}$ & $\begin{array}{c}46 \\
(92.0)\end{array}$ & 0.74 \\
\hline Hypertension & $\begin{array}{c}28 \\
(25.2)\end{array}$ & $\begin{array}{c}13 \\
(17.6)\end{array}$ & 0.22 & $\begin{array}{c}8 \\
(25.8)\end{array}$ & $\begin{array}{c}9 \\
(30.0)\end{array}$ & $\begin{array}{c}11 \\
(22.0)\end{array}$ & 0.73 \\
\hline
\end{tabular}

Within parentheses are percentages over column total of respective variable

Chi-square test or Fisher's exact test was done as appropriate

II According to Mayo clinic smoking status category ${ }^{14}$

$¥$ According to international physical activity questionnaire- short form ${ }^{15}$

$\dagger$ At least 10 minutes a day in between 11 am to $2 \mathrm{pm}$, at least 3 days a week ${ }^{16}$

T According to WHO, western pacific region, $2000^{17}$

The mean value of serum iPTH was significantly higher in the people of control group in comparison to the prediabetes $(p=0.003)$ group. The mean value of vitamin $\mathrm{D}$ in people with prediabetes was higher but not significantly different from the control population. Among the different categories of prediabetes, there were also no statistically significant associations of the mean value of any biochemical variables including vitamin D (Table 3).

Table 3. Biochemical variables in the study population $(\mathrm{N}=\mathbf{1 8 5})$

\begin{tabular}{|c|c|c|c|c|c|c|c|}
\hline \multirow{3}{*}{ Variables } & \multirow{2}{*}{$\begin{array}{l}\text { Prediabetes } \\
(\mathrm{n}=111)\end{array}$} & \multirow{2}{*}{$\begin{array}{c}\text { Control } \\
\text { NGT }(n=74)\end{array}$} & \multirow{3}{*}{$\mathrm{p}$} & \multicolumn{3}{|c|}{ Prediabetes categories } & \multirow{3}{*}{$\mathrm{p}$} \\
\hline & & & & $\operatorname{IFG}(\mathrm{n}=31)$ & $\operatorname{IGT}(\mathrm{n}=30)$ & $\mathrm{IFG}+\mathrm{IGT}(\mathrm{n}=50)$ & \\
\hline & \multicolumn{2}{|c|}{ mean $\pm \mathrm{SD}(\min , \max )$} & & \multicolumn{3}{|c|}{ mean $\pm \mathrm{SD}$ (min, max) } & \\
\hline $\begin{array}{l}\text { S. corrected calcium } \\
(\mathrm{mg} / \mathrm{dl})\end{array}$ & $\begin{array}{c}9.24 \pm 0.51 \\
(7.86,10.36)\end{array}$ & $\begin{array}{c}9.12 \pm 0.54 \\
(7.7,10.28)\end{array}$ & 0.10 & $\begin{array}{c}9.32 \pm 0.59 \\
(7.86,10.18)\end{array}$ & $\begin{array}{l}9.18 \pm 0.49 \\
(8.2,10.0)\end{array}$ & $\begin{array}{c}9.25 \pm 0.48 \\
(7.98,10.36)\end{array}$ & 0.55 \\
\hline $\begin{array}{l}\text { S. inorganic phosphate } \\
(\mathrm{mg} / \mathrm{dl})\end{array}$ & $\begin{array}{c}3.58 \pm 0.48 \\
(2.60,4.90)\end{array}$ & $\begin{array}{l}3.70 \pm 0.51 \\
(2.6,5.1)\end{array}$ & 0.12 & $\begin{array}{c}3.49 \pm 0.54 \\
(2.6,4.4)\end{array}$ & $\begin{array}{c}3.64 \pm 0.40 \\
(3.1,4.6)\end{array}$ & $\begin{array}{c}3.60 \pm 0.48 \\
(2.6,4.9)\end{array}$ & 0.43 \\
\hline $\begin{array}{l}\text { S. iPTH } \\
(\mathrm{pg} / \mathrm{ml})\end{array}$ & $\begin{array}{l}47.11 \pm 23.81 \\
(11.7,122.0)\end{array}$ & $\begin{array}{l}57.48 \pm 22.63 \\
(16.8,122.3)\end{array}$ & 0.003 & $\begin{array}{l}50.22 \pm 31.48 \\
(12.9,119.1)\end{array}$ & $\begin{array}{c}43.31 \pm 17.98 \\
(11.7,86.9)\end{array}$ & $\begin{array}{l}47.46 \pm 21.44 \\
(17.6,122.0)\end{array}$ & 0.55 \\
\hline $\begin{array}{l}\text { S. 25(OH)D } \\
(\mathrm{ng} / \mathrm{ml})\end{array}$ & $\begin{array}{c}20.78 \pm 10.60 \\
(2.0,45.47)\end{array}$ & $\begin{array}{l}19.20 \pm 8.49 \\
(2.0,37.56)\end{array}$ & 0.28 & $\begin{array}{c}22.53 \pm 11.32 \\
(2.0,45.47)\end{array}$ & $\begin{array}{l}19.70 \pm 10.61 \\
(2.0,40.82)\end{array}$ & $\begin{array}{c}20.36 \pm 10.21 \\
(2.0,40.20)\end{array}$ & 0.54 \\
\hline
\end{tabular}

Independent-samples T test or one way ANOVA was done as appropriate 

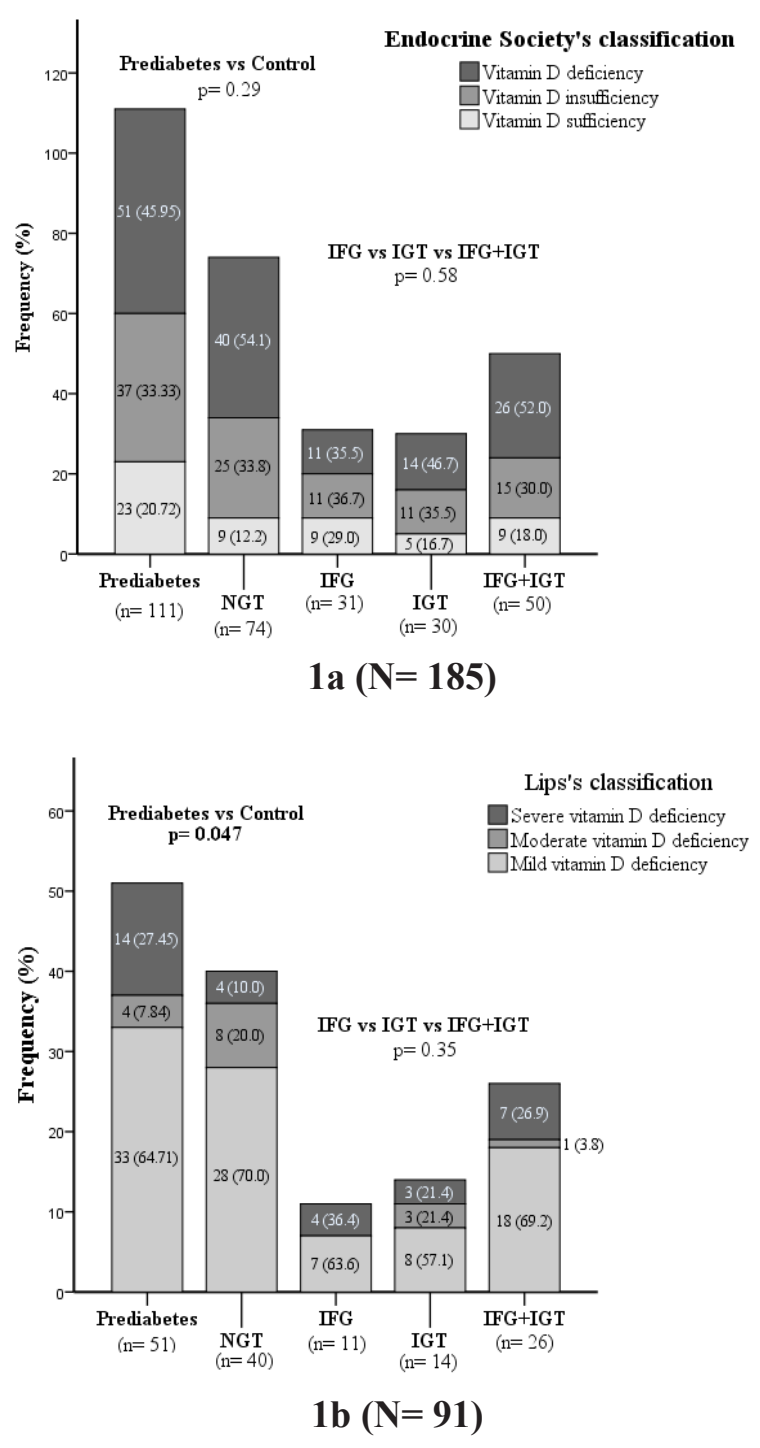

Within parentheses are percentages over column total

Chi-square test or Fisher's exact test was done as applicable

Figure 1. Vitamin D status of the study population according to: a) Endocrine society's criteria and b) Lips's criteria

According to Endocrine society's criteria the percentages of vitamin D deficiency were higher in the control population than the prediabetes group but was not significantly different $(54.1 \%$ vs $45.9 \% ; p=0.29)$. Among the different categories of prediabetes, the IFG+IGT group was followed by IGT group and at last IFG group depending on the higher percentages of vitamin D deficiency without any statistically significant association (Figure 1a). Severe vitamin D deficiency status was significantly higher in the people with prediabetes than the control group (27.5\% vs $10.0 \%$; $p=0.05)$ according to Lips's criteria. On the other hand, the IFG+IGT group has the highest frequency of severe vitamin D deficiency, however again without any statistically significant association with other categories of prediabetes (Figure 1b).

Among adults with prediabetes, the people with vitamin D deficiency $(<20 \mathrm{ng} / \mathrm{ml})$ had significantly more family history of DM, lower corrected serum calcium but higher blood glucose value 2 hours after $75 \mathrm{gm}$ glucose (2H-OGTT) and iPTH level than the people with vitamin D sufficiency ( $\geq 30 \mathrm{ng} / \mathrm{ml}$ ). But, there were no significant difference in fasting blood glucose (FBG), HbA1c\% and serum inorganic phosphate between the people of two groups (Table 4).

Table 4. Clinical and biochemical variables in people with prediabetes with vitamin $D$ deficiency $(<20 \mathrm{ng} / \mathrm{ml})$ vs vitamin D sufficiency $(\geq 30 \mathrm{ng} / \mathrm{ml})$ group $(\mathrm{N}=74)$

\begin{tabular}{|c|c|c|c|}
\hline \multirow{2}{*}{ Variables } & $\begin{array}{c}\text { Vitamin D } \\
\text { sufficiency } \\
(n=23)\end{array}$ & $\begin{array}{c}\text { Vitamin D } \\
\text { deficiency } \\
(n=51)\end{array}$ & \multirow{2}{*}{$\mathbf{p}$} \\
\hline & \multicolumn{2}{|c|}{$\begin{array}{c}\text { frequency }(\%) \text { or } \\
\text { mean } \pm \text { SD }\end{array}$} & \\
\hline $\begin{array}{l}\text { Family } \\
\text { history of DM }\end{array}$ & $11(47.8)$ & $38(74.5)$ & 0.025 \\
\hline $\begin{array}{l}\text { FBG } \\
(\mathrm{mmol} / \mathrm{L})\end{array}$ & $5.82 \pm 0.62$ & $5.85 \pm 0.58$ & 0.85 \\
\hline $\begin{array}{l}\text { 2H-OGTT } \\
\text { glucose } \\
(\mathrm{mmol} / \mathrm{L})\end{array}$ & $7.42 \pm 1.84$ & $8.47 \pm 1.42$ & 0.009 \\
\hline HbA1c (\%) & $5.74 \pm 0.41$ & $5.82 \pm 0.37$ & 0.40 \\
\hline $\begin{array}{l}\text { Serum } \\
\text { corrected } \\
\text { calcium (mg/ } \\
\text { dl) } \\
\end{array}$ & $9.51 \pm 0.52$ & $9.13 \pm 0.45$ & 0.002 \\
\hline $\begin{array}{l}\text { Serum } \\
\text { inorganic } \\
\text { phosphate } \\
(\mathrm{mg} / \mathrm{dl})\end{array}$ & $3.47 \pm 0.42$ & $3.69 \pm 0.54$ & 0.09 \\
\hline $\begin{array}{l}\text { Serum iPTH } \\
(\mathrm{pg} / \mathrm{ml})\end{array}$ & $42.00 \pm 24.74$ & $54.69 \pm 25.20$ & 0.047 \\
\hline
\end{tabular}

Chi-square test or independent-samples T test was done as appropriate 
No significant correlations were found between vitamin D level with blood glucose in fasting ( $\mathrm{r}=$ $0.007 ; \mathrm{p}=0.94), 2 \mathrm{H}$-OGTT $(\mathrm{r}=-0.16 ; \mathrm{p}=0.09)$ and $\mathrm{HbA} 1 \mathrm{c} \%(\mathrm{r}=-0.12 ; \mathrm{p}=0.20)$ in adults with prediabetes.

Logistic regression analysis revealed that severe vitamin $\mathrm{D}$ deficiency (vitamin $\mathrm{D}<5 \mathrm{ng} / \mathrm{ml}$ ) did not increase the risk of developing of prediabetes (Odds ratio, $\mathrm{OR}=0.48, \mathrm{p}=0.17$ ) or any category of prediabetes (IFG: $\mathrm{OR}=0.76, \mathrm{p}=0.67$; IGT: $\mathrm{OR}=$ $0.99, \mathrm{p}=0.98$; IFG+IGT: $\mathrm{OR}=0.8, \mathrm{p}=0.69)$.

\section{Discussions}

This study is aimed to determine the vitamin D level \& status among adults with prediabetes (in comparison to control population) and its different categories. There were no significant differences in vitamin D level and status between people with and without prediabetes except for frequency of severe vitamin D deficiency, which was higher in those with prediabetes. There were also no significant differences in vitamin $\mathrm{D}$ level and status among the different categories of prediabetes. In addition, vitamin D level did not correlate with different blood glucose levels in people with prediabetes. Severe vitamin D deficiency was not associated with increased risk of prediabetes. Among people with prediabetes, family history of DM was significantly more common, corrected serum calcium was significantly lower, serum iPTH and 2H-OGTT glucose value were significantly higher in people with vitamin $\mathrm{D}$ deficiency.

The mean vitamin D level in the people with prediabetes was in the insufficiency group according to Endocrine society's criteria and was not significantly different from the control group. Similar findings were also observed by other studies ${ }^{19,20}$. This lower level of vitamin D might be the cause of significantly higher iPTH level in the control group.

The mean vitamin D level in the people with different categories of prediabetes was also not statistically different in our study. Scragg et al. observed mean vitamin D level $28 \pm 12.5 \mathrm{ng} / \mathrm{ml}$ (vitamin D insufficiency) in IGT group ${ }^{21}$. Another study only showed IFG criteria to define prediabetes and found mean vitamin D level $23.6 \pm 0.7 \mathrm{ng} / \mathrm{ml}$ that was similar to our finding $(22.53 \pm 11.32 \mathrm{ng} / \mathrm{ml})$. However, this IFG group might have IGT simultaneously ${ }^{19}$. Based on $\mathrm{HbAlc}$, one study did not find any significant difference of mean vitamin $\mathrm{D}$ level in a group of young women with prediabetes ${ }^{22}$. One study found significantly higher mean vitamin D level and lower serum calcium level in the people of NGT group that were not consistent with our findings ${ }^{23}$.

According to Endocrine society's criteria, $45.9 \%$ of the adults with prediabetes were vitamin D deficient and were not significantly different from the control group. Similar findings were also observed by other authors ${ }^{24,25}$. On the other hand, high prevalence of vitamin D deficiency was found by some studies in the people with prediabetes ${ }^{26-28}$. This might be due to a relatively higher age, greater percentages of smokers and higher BMI in these study population. Besides these, history of sunlight exposure and use of sunscreen were not mentioned in these studies.

This study found $27.5 \%$ of the adults with prediabetes with severe vitamin D deficiency with a cut off $5 \mathrm{ng} /$ $\mathrm{ml}$, which was significantly higher than the control population. Using a cut off $10 \mathrm{ng} / \mathrm{ml}$, Dutta et al. found $14.65 \%$ of the prediabetic populations were severely vitamin D deficient. Ayhan et al. and Ahmed et al. found higher percentages $(50.43 \%$ and $47.5 \%$ respectively) of severe vitamin D deficiency among the prediabetic group ${ }^{20,26,28}$.

In the natural history of development of prediabetes, at first IGT is developed followed by $\mathrm{IFG}^{28}$. However, they may appear separately and have separate course of progression ${ }^{30}$. So, with the advancement of glycemic status higher percentages of vitamin D deficiency are expected. We also found, highest percentages of severe vitamin D deficiency in the IFG+IGT group without any significant associations with other categories of prediabetes. One study described prediabetes as two mutually exclusive groups of raised HbA1c $(5.7 \%$ - 6.4\%) \& IFG/IGT and found no significant association with serum calcium, phosphate, parathormone and $25(\mathrm{OH}) \mathrm{D}^{31}$.

We observed that, vitamin D deficiency $(<20 \mathrm{ng} / \mathrm{ml})$ was associated with significantly lower corrected serum calcium and higher $\mathrm{iPTH}$ in comparison to vitamin D sufficiency ( $\geq 30 \mathrm{ng} / \mathrm{ml}$ ) in the people with prediabetes. We also found that people with vitamin D deficiency had significantly more family history of DM ang higher level of 2H-OGTT glucose values. One study found significantly more family history of DM and higher FBG in vitamin D deficiency group than sufficiency group among Indian women with prediabetes $^{32}$. Abbasi et al. did not find significant difference in FBG between vitamin D deficiencies than sufficiency group ${ }^{19}$. Dutta et al. also did not 
find any association of FBG, 2H-OGTT glucose and $\mathrm{HbA1c}$ with different categories of vitamin D status in people with prediabetes ${ }^{20}$.

We did not find any significant correlations of fasting, 2H-OGTT glucose and $\mathrm{HbAlc}$ value with vitamin D level. Gioreli et al. didn't find any association of vitamin D with fasting and 2H-OGTT glucose values $^{33}$. No correlation between HbA1c and vitamin $\mathrm{D}$ was also found by other studies ${ }^{20,22}$. Data from the National Health and Nutrition Examination survey found a negative correlation between vitamin D level and $\mathrm{HbA1c}$ among US adults of a specific age group who reported them as free from $\mathrm{DM}^{34}$. Another study also found negative correlation of FBG and $2 \mathrm{H}-\mathrm{OGTT}$ glucose values with vitamin D level ${ }^{33}$. Although low vitamin D level was associated with increased risk of prediabetes, vitamin D supplementation failed to show improvement of glycemic status indicating a minor role of vitamin D in preventing $\mathrm{DM}^{35}$.

Even severe vitamin D deficiency state $(<5 \mathrm{ng} / \mathrm{ml})$ did not significantly increase the risk of prediabetes or any category of prediabetes in our study. One study found vitamin D deficiency $(<20 \mathrm{ng} / \mathrm{ml})$ did not increase the risk of development of prediabetes and another study found increased risk of development of IGT but not IFG or combined IFG+IGT group ${ }^{23,36}$. Compared with $\geq 30 \mathrm{ng} / \mathrm{ml}$, serum $25(\mathrm{OH})$ D level $<10$ $\mathrm{ng} / \mathrm{ml}$ was found to increase risk of development of IFG in a large population with age $40-70$ years. The association might be variable depending on age, sex and race $^{37}$. So, the progression of prediabetes to DM depends on interaction of many factors. As this was a cross-sectional study, a longitudinal prospective study conducted in community level could reveal the true association of vitamin D and prediabetes among people of Bangladesh.

\section{Conclusion}

Among different vitamin D levels, only frequency of severe vitamin D deficiency was higher in people with prediabetes compared to control. There was no association between vitamin $\mathrm{D}$ with prediabetes and its categories or blood glucose levels in those with prediabetes. Vitamin D deficiency $(<20 \mathrm{ng} / \mathrm{ml})$ was associated with family history of DM, lower level of corrected serum calcium, higher level of blood glucose after glucose meal and iPTH among adults with prediabetes.

\section{Manuscript word count: 2390}

\section{Acknowledgements}

We would like to acknowledge the department of Biochemistry, BSMMU and Center for Advance Research in Sciences, Dhaka University for their support in biochemical analysis.

\section{Funding statement:}

We are grateful to Beximco Pharmaceuticals Limited for financial support for measurement of vitamin D and BSMMU for thesis grant.

\section{Conflict of interest}

None of the authors have any conflict of interest.

\section{Data availability statement}

The data that support the findings of this study are available from the corresponding author upon reasonable request.

\section{Author contributions:}

MMS was involved in protocol writing, data analysis and manuscript writing. FM and HT designed the study and were the direct supervisors throughout the study period. MMS, YA, FI, GI and SA were involved in data collection and vitamin D analysis. All authors including SS, KMA, HMA, MM and $\mathrm{RMH}$ interpreted the data, drafted and revised the manuscript and approved the final version of the manuscript for publication. 
Bangladesh Journal of Medical Science Vol. 21 No. 01 January'22

\section{References}

1. International Diabetes Federation. IDF Diabetes Atlas, $9^{\text {th }}$ edition, Brussels, Belgium 2019. https://www. diabetesatlas.org. Accessed Apr 27 2020.

2. American Diabetes Association. 2. Classification and diagnosis of diabetes: standards of medical care in diabetes-2018. Diabetes care 2018;41:S13-S27. DOI: $10.2337 /$ dc18-S002. Accessed Apr 27 $7^{\text {th }} 2020$.

3. Kalra S. Recent advances in pathophysiology of diabetes: beyond the dirty dozen. J Pakistan Med Assoc 2013;63(2):277-280. https://jpma.org.pk/articledetails/4015?Article_id=4015.

4. Nakashima A, Yokoyama K, Yokoo T, Urashima M. Role of vitamin D in diabetes mellitus and chronic kidney disease. World J Diabetes 2016;7(5):89-100. DOI: $10.4239 /$ wjd.v7.i5.89.

5. Naeem Z. Vitamin D deficiency- an ignored epidemic. Int J Health Sciences 2010;4(1):V-VI. https://www.ncbi. nlm.nih.gov/pmc/articles/PMC3068797/pdf/ijhs-4-1005a.pdf.

6. Afrin SF, Rahman MH, Bari KF, Al Mahmood AK. Status of Vitamin D by measuring 25-Hydroxyvitamin D level in Dhaka City. Bangladesh J Med Sci 2019;18(3):624-7. DOI: https://doi.org/10.3329/bjms.v18i3.41638.

7. Anwar T, Rahman M, Mollah F, Biswas S. Association of serum vitamin D3 with newly diagnosed type 2 diabetes mellitus. BSMMU J 2018;11(1):99-101. https:// doi.org/10.3329/bsmmuj.v11i1.35942.

8. Alam MS, Kamrul-Hasan M, Kalam ST, Selim S, Akter F, Saifuddin M. Vitamin D status in newly diagnosed type 2 diabetes patients attending in a tertiary hospital of Bangladesh. Mymensingh Med J 2018;27(2):362-8. https://www.researchgate.net/publication/325253454.

9. Zinnat R, Hossain IA, Ali L. Association between vitamin $\mathrm{D}$ and insulin resistance with noninvasive markers among prediabetic individuals with nonalcoholic fatty liver disease. Proceedings of the $54^{\text {th }}$ annual meeting of the European Association for the Study of Diabetes, Berlin, Germany Oct 2018.Https://www.researchgate. net/publication/328497148.

10. Holick MF, Binkley NC, Bischoff-Ferrari HA, Gordon CM, Hanley DA, Heaney RP, et al. Evaluation, treatment, and prevention of vitamin D deficiency: an Endocrine Society clinical practice guideline. J Clin Endocrinol Metab 2011;96(7):1911-30. DOI:10.1210/jc.2011-0385

11. Lips P. Which circulating level of 25-hydroxyvitamin D is appropriate? J Steroid Biochem Mol Biol 2004;89:611-
4. DOI: 10.1016/j.jsbmb.2004.03.040.

12. Islam N. Bangladesh national conservation strategy: urbanization, housing and settlement planning 2013. http://bforest.portal.gov.bd/sites/default/files/ files/bforest.portal.gov.bd/notices/c3379d22 ee62 4dec 9e29 75171074d885/9.\%20Urbanization NCS.pdf. Accessed Apr $27^{\text {th }} 2020$.

13. Hyppönen E, Boucher BJ, Berry DJ, Power C. 25-hydroxyvitamin D, IGF-1, and metabolic syndrome at 45 years of age: a cross-sectional study in the 1958 British Birth Cohort. Diabetes 2008;57(2):298-305. DOI:10.2337/db07-1122

14. Hossain HT, Islam QT, Khandaker MA, Ahasan HN. Study of serum vitamin D level in different sociodemographic population- a pilot study. JMed 2018;19:2229. DOI: https://doi.org/10.3329/jom.v19i1.34836 .

15. Sohn S, Savova GK. Mayo clinic smoking status classification system: extensions and improvements. Proceedings of the AMIA annusymp 2009;2009:619. American Med Inform Assoc. PMID: 20351929. PMCID: PMC2815365 https://www.ncbi.nlm.nih.gov/pmc/articles/ PMC2815365/pdf/amia-f2009-619.pdf.

16. Craig CL, Marshall AL, Sjöström M, Bauman AE, Booth ML, Ainsworth BE, et al. International physical activity questionnaire: 12-country reliability and validity. Med Sci Sports Exerc 2003;35(8):1381-95. DOI: 10.1249/01. MSS.0000078924.61453.FB.

17. Harinarayan CV, Holick MF, Prasad UV, Vani PS, Himabindu G. Vitamin D status and sun exposure in India. Dermato-endocrinology 2013;5(1):130-41. DOI: $10.4161 /$ derm.23873.

18. World Health Organization. The Asia-Pacific perspective: redefining obesity and its treatment. Australia: Health Communiation 2000. https://apps. who.int/iris/handle/10665/206936.

19. Abbasi F, Blasey C, Feldman D, Caulfield MP, Hantash FM, Reaven GM. Low circulating 25-hydroxyvitamin $\mathrm{D}$ concentrations are associated with defects in insulin action and insulin secretion in persons with prediabetes. J Nutr 2015;145(4):714-9. DOI: 10.3945/jn.114.209171.

20. Dutta D, Maisnam I, Shrivastava A, Sinha A, Ghosh S, Mukhopadhyay PK, et al. Serum vitamin-D predicts insulin resistance in individuals with prediabetes. Ind $J$ Med Res 2013;138(6):853-60. http://www.ijmr.org.in/ article.asp?Issn=0971-5916; year=2013; volume=138; iss ue $=6$; spage $=853$; epage $=860$; aulast $=$ Dutta . 
21. Scragg R, Holdaway I, Singh V, Metcalf P, Baker J, Dryson E. Serum 25-hydroxyvitamin D3 levels decreased in impaired glucose tolerance and diabetes mellitus. Diabetes res clin pract 1995;27(3):181-8. https://doi.org/10.1016/0168-8227(95)01040-K.

22. Al-Mohaissen MA, Lee T, Alamri AF. Vitamin D levels, prediabetes risk and hemoglobin A1c levels in young non-diabetic Saudi women. J Diabetes Investig 2020;10. Epub 2020 Feb 4. https://doi.org/10.1111/jdi.13226.

23. Gultekin M, Zeliha H, Derya O, Ogun H, Pinar A, Bilgin $\mathrm{O}$, et al. Vitamin D level in impaired fasting glucose and impaired glucose tolerance (prediabetic) patients. Proceedings of the $17^{\text {th }}$ European Congress of Endocrinology 2015 May 16-20; Dublin, Ireland. Bioscientifica 37(2015). DOI: 10.3252/pso. eu. 17 ece. 2015 .

24. Giri R, Verma RK, Jain A, Srivastava V. Status of vitamin D3 level and its co-relation with the glycaemic status in Indian population. Int J Advances Med 2017;4(4):1067. http://dx.doi.org/10.18203/2349-3933.ijam20173233.

25. Esteghamati A, Aryan Z, Esteghamati AR, Nakhjavani M. Vitamin D deficiency is associated with insulin resistance in nondiabetics and reduced insulin production in type 2 diabetics. Horm Metab Res 2015;47(4):273279. DOI:10.1055/s-0034-1389903.

26. Ayhan R, Türker BÇ, Ahbab S, Türker F, Ataoğlu HE. Low serum vitamin $\mathrm{D}$ associated with prediabetes. Int J Community Med Public Health 2018;5(9):3776-81. DOI: 10.18203/2394-6040.ijcmph20183563.

27. Kwon HN, Lim H. Relationship between serum vitamin D status and metabolic risk factors among Korean adults with prediabetes. Plos One 2016;11(10):e0165324. DOI:10.1371/journal.pone.0165324.

28. Ahmed MM, Zingade US, Badaam KM, Khan ST. Prevalence of vitamin D deficiency in prediabetes and its correlation with glycemic indices: a crosssectional pilot study. Res J Pharmaceu Biolog Chem Scien 2014;5(4):1340-4. Https://www.researchgate.net/ publication/286116391.

29. Ramlo-Halsted BA, Edelman SV. The natural history of type 2 diabetes: implications for clinical practice. Prim Care 1999;26(4):771-789. DOI:10.1016/s00954543(05)70130-5
30. Faerch K, Vaag A, Holst JJ, Hansen T, Jørgensen T, Borch-Johnsen K. Natural history of insulin sensitivity and insulin secretion in the progression from normal glucose tolerance to impaired fasting glycemia and impaired glucose tolerance: the Inter 99 study. Diabetes care 2009;32(3):439-44. DOI: 10.2337/dc08-1195.

31. Zagami RM, Di Pino A, Urbano F, Piro S, Purrello F, Rabuazzo AM. Low circulating vitamin D levels are associated with increased arterial stiffness in prediabetic subjects identified according to HbA1c. Atherosclerosis 2015;243(2):395-401. DOI: 10.1016/j. atherosclerosis.2015.09.038.

32. Bhatt SP, Misra A, Gulati S, Singh N, Pandey RM. Lower vitamin D levels are associated with higher blood glucose levels in Asian Indian women with pre-diabetes: a population-based cross-sectional study in North India. BMJ Open Diabetes Res Care 2018;6(1):e00501. DOI:10.1136/bmjdrc-2017-000501.

33. Giorelli GD, Matos LN, Saado A, Soibelman VL, Dias CB. Ausência de associação entre níveis de 25-hidroxivitamina $\mathrm{D}$ e pré-diabetes empacientesbrasileiros.Um estudo transversal. Sao Paulo Med J 2015;133(2):73-7. DOI: 10.1590/15163180.2013.7180005.

34. Kositsawat J, Freeman VL, Gerber BS, Geraci S. Association of A1C levels with vitamin D status in U.S. adults: data from the National Health and Nutrition Examination Survey. Diabetes Care 2010;33(6):12361238. DOI:10.2337/dc09-2150.

35. Yu L, Zhai Y, Shen S. Association between vitamin $\mathrm{D}$ and prediabetes: A PRISMA-compliant metaanalysis. Medicine (Baltimore) 2020;99(8):e19034. DOI:10.1097/MD.0000000000019034.

36. Sankarappan S. Association of vitamin D deficiency with prediabetes among elderly New Mexicans [dissertation] University of New Mexico; 2013. https:// digitalrepository.unm.edu/biom_etds/74.

37. Tsur A, Tsur A, Feldman BS, Feldhammer I, Hoshen MB, Leibowitz G, et al. Decreased serum concentrations of 25-hydroxycholecalciferol are associated with increased risk of progression to impaired fasting glucose and diabetes. Diabetes Care 2013;36(5):1361-7. DOI: $10.2337 / \mathrm{dc} 12-1050$. 